\title{
Integration of Technology in Teaching of Science at Secondary Level in City Muzaffarabad
}

Asma $\mathrm{Zia}^{1}$, Ayesha Ashraf ${ }^{2}$

\begin{abstract}
It is becoming challenging to prepare learners for technological age and use of technology tools in schools. Teachers are integrating technology in schools for instructional purposes. Integrating technology in many content areas is supporting learning, educational environment and enhancing skills of students. Integration of technology is not merely a synonym of computers. The present study is about the integration of technology in teaching of science. The objectives of the study were to explore the current status of instructional technology tools and resources in classroom at secondary level, to identify the effect on learning attitudes of students and to examine the importance of instructional technology for science teachers. This study focused on the current status of the use of technology in the classrooms and about the use of appropriate teaching skills. 100 participants were the sample size of the study. In this study two questionnaires were administered to collect data on availability of technology tools and resources in secondary schools along with exploring the status of integrating technology in teaching science at secondary level in city Muzaffarabad. Data analysis revealed that most of the technology resources and tools are available in secondary school of city Muzaffarabad and secondary school teachers are using them in teaching of science. Integration of the technology while teaching learning process benefits the science teachers in the following ways: eases the pressure on them while teaching, professional development, and classroom management and in enhancing their pedagogical skills. Other dimension of this study can be used to measure the students' performance and their attitude towards learning while integrating technology in teaching science.
\end{abstract}

Keywords: Integration, Technology, Teaching of science, Secondary level

\footnotetext{
${ }^{1}$ Lecturer, Institute of Education, University of Azad Jammu \& Kashmir, Muzaffarabad Email: asmazia04@gmail.com

${ }^{2}$ M.Phil Scholar, Institute of Education, University of Azad Jammu \& Kashmir, Muzaffarabad
} 


\section{Introduction}

Integration of technology for educational purpose is process of arranging technology resources and tools in such a way that enhances quality education. Integrating technology in teaching is not only the amount or type of technology used, but by how and why it is used for instructional purpose. Although, technology gives access to huge set of knowledge and information, but it is not pedagogically sound. This means teacher must become expert in pedagogical design of information. In other way, technology is perceived as number of technological tools and resources that add comfort to our daily life. However, it is regarded as any machinery with practical applications and having specific purposes. In this sense technology is not perceived as the logical application of scientific and other planned knowledge to practical tasks (Galbraith, 1967). For today's style of teaching, both teachers and students are using technology for instructional purposes. Teachers not only demand skills and expertise for using technology, but also a technology sound portfolio (Wallace, 2011).

In educational setting, teachers who teach science are regarded as visionaries for using instructional technology. Technology has been used in different teaching methods, inside the science labs for experiments and for research purpose. However, using technology requires skill and support to teachers. Teachers reported that although they have access to technology resources but they could not use it properly in labs or for data collection. Computers labs in schools were equipped, but teacher needed adequate guidance to use it in teaching. They were not well prepared to use the technology for instructional purposes (Becker, Ravitz \& Wong, 1999).

Instructional complexities might lead to some social problems as well as that related to other technology machines. Teachers should have the skills and knowledge to select suitable software that fulfills instructional needs. Only common knowledge about technology products is not enough for the effective use in teaching (Cassidy, 1982). Another point about having general knowledge for use of technology is that, it is not sufficient knowledge and fulfills demand of good teaching. Teachers must redesign the general skills about technology into more specific style, so that technologies can be used in classrooms. Being able to know the use of computer is not as similar as using computer to teach a specific subject. Rather solution to this problem demands that teacher need to know collection, selection of technologies and range to use technologies that can foster learning. These devices like computers, websites and specific softwares (Wallace 2011).

Means, Blando, Oslon, Middle, Morocco \& Remz (1993) stated that when technology tools are used efficiently and effectively; they can support 
higher-order thinking abilities by engaging pupils in complex, genuine tasks within collaborative learning settings. Researchers are discovering other zones of research at technology and also investigating about influences of instructional technologies on learning due to quick change in informational and communicational technology (Morrison, Ross, Kemp \& Kalman, 2010).

\subsection{Objectives of Study}

The study was aimed at following objectives:-

1. To explore the current status of instructional technology in secondary level classrooms.

2. To identify the effect of instructional technology on learning attitudes of students.

3. To examine the importance of instructional technology for science teachers.

\subsection{Significance of Study}

This study contributes to elaborate that teacher's professional identities influence their use and choice of teaching and learning strategies and also influence students in classroom. The study provides information that explains which instructional technologies are used in today's science classrooms and why teachers need to choose particular strategies to integrate technology in science classrooms.

The findings from this study would be helpful for teachers, curriculum developers and administrators about the use of technology tools at secondary level classrooms. This study will be also helpful in understanding the need of instructional technology in secondary science teaching and importance of technology to foster both teaching and students leaning attitudes towards science. The study can be helpful for pre-service teachers to assist classroom in modern ways and to make pedagogically sound teaching material. As technology is one of the basic requirement of any education system and it makes the teaching productive because students learn effectively by practical activities rather than rote memorization. This study is helpful for the policy makers, secondary school heads and teachers to understand the existing technological tools used in the schools and educational institutions. These professionals would come to know about the learning attitude of the students and how these technological tools effect the students learning. The policy makers can design their next educational policy according to the existing technological facilities provided to the different schools and can plan about the future in a better way.

\subsection{Delimitation of Study}

Due to the shortage of time and resources the study was delimited to the 10 secondary schools of Muzaffarabad where science subjects are being taught. 


\section{Literature Review}

Educational implications of technology allow students to learn at their own pace. It fits with learning style of students because of including variety of tools. Traditional learning and teaching has been replaced by multimedia use in classroom that creates a difference between modern and old teaching and learning. Technology is more efficient than traditional teaching as feedback is collected more easily through educational technology (Clark, 1983). Studies have revealed that comparison between traditional method and computer guided instructions promote learning if both are used adequately. However, it was observed that there exists a difference between using technological tools for learning and learning through traditional method (Dynarski et al., 2007).

In science learning it is essential for teachers to understand technology in broad perspective. Teachers need skills to select and identify technology tools and devices for teaching. Another important component for use of technology is a meaningful portfolio such that teachers know how some tools and resources can be used. Mechanical knowledge about technologies like knowing about hardware is not necessary for what teachers want to teach and how students want to learn (Becker, Ravitz \&Wong, 1999).

Teacher experiences his/her ongoing learning from student's responses like when students respond these activities that are technology supported, teacher analyses effectiveness of activities, which method and strategy results in better learning of students. It gives a clear picture whether technology in classroom is useful or not. Learning through response after using technology in classroom also requires use of appropriate technology tools and resources at the right time in classroom so that science learning becomes meaningful. Researches revealed that there is sufficient technology available which is still not effectively used by students as well as teachers (Cuban, Kirkpatrick \& Peck, 2001).

In developed countries professional development of teachers is carried for making use of technology in teaching. Nevertheless, difficulties in use of technology by teachers still exits. One reason is that teachers did not depend on technology for making it vital part of their teaching and another problem is that not all teachers have access to technology. In United States, computer to student ratio has raised and students have more access to technology in schools (National Center for Education Statistics, 2000).

Being a teacher, one have to know about technology in different way that is compatible with this profession. Teachers must relate technology to teaching science in their classroom. It includes different things such as which technology tool supports learning and can be used in teaching science and its usefulness for students. It is the teacher who decides where, when and which technology is 
placed in teaching (Roblyer \& Edward, 2000). Along with use of technology, for science students teacher can use inquiry techniques to foster learning science concepts more clearly. Teacher would act as facilitator to implement technology for doing science at the same time when students would learn same concepts of science without technology (Flick \& Bell, 2000).Technology tools are integral part for carrying out investigation in science; these tools help in measurements, calculation and make the investigations more clear(National Research Council, 1996).Here, a problem in integrating technology in science teaching could relate to not using technology during instructional activities. It is needed that teachers take serous measure at their own end to integrate instructional technology in curriculum of science. In effective way, using technology for content of science demands adequate teaching methods which lead to a platform where students can more clearly understand technology science relationship (Lederman, 2000). Beside traditional tools, it is needed to use modern technology tools for science teaching because students become active learners that enhance their problem solving skill and improves their thinking skills. However, recent researchers revealed that integration of technology is a continuous process that demands a strong commitment with its usage (Hughes, Kerr \& Ooms, 2005).

\section{Research Methodology}

This study was a descriptive analysis of importance of technology in teaching of science at secondary level. Survey method was used to collect the relevant data about the current study.

\subsection{Research Design}

The design used for this research was quantitative in nature. Survey was conducted to collect the data.

\subsection{Sample and Sampling Technique}

Among the target population, 50 students and 50 teachers were selected to collect the data using convenient sampling technique.

\subsection{Research Instrument}

The researcher developed two questionnaires for collecting data from both science teachers and science students of secondary level. Questionnaire was based on 5 point Likert scale in which 5 options were given, strongly agree, agree, uncertain, disagree and strongly disagree and for statements regarding availability of current technology tools and resources yes/no options were also given. 


\section{Data Analysis \& Results}

After collecting data the researcher analyzed both of the questionnaires by finding the frequency and percentage against each response of the both sample respondents. Analysis of data was done through SPSS.

Table 1

Current status of technology tools available at secondary level schools

\begin{tabular}{llll} 
S\# & \multicolumn{1}{c}{ Tools/ Resources } & \multicolumn{2}{c}{ Responses \% } \\
\cline { 3 - 4 } & & Yes & No \\
1. & Internet & 70 & 30 \\
2. & Overhead projector & 66 & 34 \\
3. & Multimedia & 60 & 40 \\
4. & Radio or tape & 52 & 48 \\
\hline
\end{tabular}

Analysis about the availability of current technology tools and resources in the secondary schools revealed that $70 \%$ respondents agreed that internet facility is available in their schools and 30\% respondents disagreed with the availability of the internet facility. $66 \%$ respondents were in the favor that the overhead projector is available in their school and $34 \%$ were not in favor of the availability of the projector. $60 \%$ participants agreed upon the availability of multimedia and $52 \%$ respondents also agreed that radio and tape is available in their school.

Table 2

Classroom Management, Pedagogical Skills, Professional Development

\begin{tabular}{|c|c|c|c|c|c|c|}
\hline S\# & Statement & \multicolumn{5}{|c|}{ Responses \% } \\
\hline & Technology in teaching science; & SA & A & UD & $\mathrm{DA}$ & SDA \\
\hline 1 & increases academic achievement of students. & 30 & 70 & 0 & 0 & 0 \\
\hline 2 & is effective I believe I can implement it. & 12 & 58 & 30 & 0 & 0 \\
\hline 3 & promotes students collaboration. & 36 & 42 & 18 & 4 & 0 \\
\hline 4 & $\begin{array}{l}\text { helps to accommodate students' personal } \\
\text { learning style. }\end{array}$ & 42 & 46 & 12 & 0 & 0 \\
\hline 5 & $\begin{array}{l}\text { motivates students to get more involved in } \\
\text { learning activities. }\end{array}$ & 50 & 36 & 14 & 0 & 0 \\
\hline 6 & is effective, if pedagogically sound. & 46 & 36 & 18 & 0 & 0 \\
\hline 7 & $\begin{array}{l}\text { gives teacher an opportunity to become } \\
\text { learning facilitator instead of only } \\
\text { information provider. }\end{array}$ & 38 & 52 & 8 & 2 & 0 \\
\hline 8 & eases pressure on me during teaching. & 36 & 52 & 6 & 2 & 4 \\
\hline 9 & $\begin{array}{l}\text { is pedagogically sound if teacher involves in } \\
\text { selection of the tools to be integrated in } \\
\text { instructions. }\end{array}$ & 28 & 62 & 6 & 4 & 0 \\
\hline
\end{tabular}


Statistical analysis of dimensions indicated that most of the respondents agreed including: $100 \%$ for the statement that technology improves in academic achievement of students, $70 \%$ for effectiveness in implementation, $86 \%$ respondents agreed that it helps to accommodate students personal learning style, $86 \%$ agreed that it motivates students in learning. $82 \%$ agreed that technology is effective if it is pedagogically sound, $90 \%$ for teacher become facilitator during teaching, $88 \%$ respondents agreed that technology eases pressure during teaching, $90 \%$ agreed that their involvement in selection of tools and resources make it pedagogically sound.

\section{Discussion}

This current study was about the integration of technology in teaching science which is still a big challenge for the secondary school teachers. There are many reasons that the teachers do not use the technological tools in their teaching because they do not have the sufficient tools in the classroom. Lack of time and expertise are obstacles in the use of technological usage in the classroom. Use of technology also benefits students for active learning and also motivates students to get involved in learning activities. According to Hadley \& Sheingold (1993), efficient technology usage encourages students for effective, individual and selfcontrolled learning.

The finding of the study shows that it becomes pedagogically sound if teacher involves in selection of the tools to be integrated in instructions. Same finding is supported by the study of Honey \& Ve (1996), that instructor' pedagogic and theoretical beliefs on learning and teaching are determined as an important element which affects whether technology is used and how it is used. Along with teachers, it is needed to motivate student to use technology tools in learning by designing activities for them.

Findings of the study revealed that instructional technology gives teacher an opportunity to become learning facilitator instead of only information provider. The same finding is supported by the study of Krajcik, Blumenfeld, Marx\& Soloway (2000). The results of the study also showed that instructional technology has the capacity to enhance teaching and learning in the classroom. Through technology, the classroom community can explore the world outside the school, communicate with other students, correspond with scientists and researchers, collect and interpret real data about real phenomena, share findings, etc. In short, computers can be used in support of inquiry in science teaching, which is defined as the opportunity to "find solutions to real problem s by asking and retaining questions, designing and conducting investigations, gathering and 
analyzing data, making interpretations, drawing conclusions, and reporting findings".

Science and technology education plays a key role for the future of societies at this present information and technology era where scientific information grows exponentially, technological innovations develop rapidly, effects of science and technology are seen clearly every area of our life. Because of this importance, especially developed countries and all others keep working on increasing the quality of science and technology education (Bayrak, Erkoç \& Gul, 2018). In this study it is found that the technology tools and resources are less available in secondary school. However, integrated instructions support modern learning system and it also enhances teacher's professional development.

\section{Conclusions}

Based on the analysis of the collected data it was found that most of the technology resources and tools are available in secondary school of city Muzaffarabad and secondary school teachers are using them during teaching of science. The teachers agreed that teaching with technology facilitate them and they get rid from the pressure on them while teaching. It is more effective and produces good results if they involve in selecting technology tools. Use of technology increases the academic achievement of students as it promotes student's collaboration and does not make classroom management more difficult. Instructional technology has been used by science teachers at secondary level for many years. Implementation of instructional technology and tools for effective, purposeful, flexible and skill focused teaching and learning science at secondary level requires the availability of resources and appropriate skills of teachers to use them. Secondary school teachers use technology tools more frequently in the science classroom.

\section{Recommendations}

Based on the findings and conclusions of the study, following recommendations were offered:

1. Technology tools availability is very less in city Muzaffarabad schools. It needs to be enhanced in schools for both science teachers and students of secondary level.

2. Training opportunities may be provided to the secondary school teachers for the usage of the technological tools.

3. Students need to be motivated towards use of technology in learning by involving them in such activities that demands technology exposure to them. 
4. Technology integrated instructions are important to be implemented in science learning because it provides modern learning to student and professional development to teachers.

5. Awareness about need, effectiveness and reason to integrate technology in science teaching should be provided to science teachers of secondary level.

6. Science teachers should be involved while planning the allocation of budget for the technological instructional tools as they are more aware about the need ad type of these tools.

\section{References}

Bayrak, K. B., Erkoç, F. M., \& Gül, O.M., (2018) Integration application in interdisciplinary teaching: case of science and technology areas. Retrieved from https://files.eric.ed.gov/fulltext/ED500185.pdf

Becker, H. J., Ravitz, J. L., \& Wong, Y. (1999).Teacher and teacher-directed student use of computers and software .Center for Research on Information Technology and Organizations (CRITO), University of California, Irvine.

Cassidy, M.F. (1982).Towards integration: Education instructional technology and semiotics. Educational Communications and Technology Journal, 20(2), 75-89.

Clark, R. E. (1983). Reconsidering the research on learning from media. Review of Educational Research, 53(4), 445-459.

Cuban, L., Kirkpatrick, H., \& Peck, C. (2001). High access and low use of technologies in high school classrooms: Explaining an apparent paradox. American Education Research Journal, 38(4), 813-834.

Dynarski, M., Agodini, R., Heaviside, S., Novak, T., Carey, N., Campuzano, L., Means, B., Murphy, R., Penuel, W., Javitz, H., Emery, D., \& Sussex, W. (2007). Effectiveness of reading and mathematics software products: Findings from the first student cohort. Washington, DC: Institute of Education Sciences.

Flick, L., \& Bell, R. (2000). Preparing tomorrow's Science Teachers Educators. CITE Journal. Contemporary Issues in Technology and Teacher Education. 1(1), 39-60.

Galbraith, J.K. (1967). The new industrial state .Boston: MA Houghton Mifflin. 
Hadley, M., \& Sheingold, K. (1993). Commonalities and distinctive patterns in teachers' integration of computers. American Journal of Education, 101(5), 261-315.

Honey, M., \& Ve, R. B., (1996). Teacher's Beliefs and Technology Integration: Different Values, Different Under-standings. Center for Technology in Education, New York.

Hughes, J., Kerr, S., \& Ooms, A. (2005). Content-focused technology inquiry groups: Cases of teacher learning and technology integration. Journal of Educational Computing Research, 32(5) 367-378.

Krajcik, J., Blumenfeld, P., Marx, R. W., \& Soloway, E (2000). Instructional, curricular and technological supports for inquiry in science classroom. In J. Minstrell \& E. H. Van Zee (Eds), Inquiring into inquiry learning and teaching in science (pp.283-315), Washington, D.C: American Association for the Advancement of Science.

Lederman, N. G. (2000). Technocracizing Science Teaching and Learning: A Response to Flick and Bell. Retrieved form https://www.citejournal.org/volume-1/issue-1-

00/science/technocracizing-science-teaching-andlearning-a-response-toflick-and-bell/

Means, B. J., Blando, K., Oslon, T., Middle, C., Morocco, A., Remz, J. Z. (1993). Using Technology to Support Education Reform U.S Department of Education, Washington D.C. Retrieved form www.ed .gov/pubs/EdReformStudies/TechReforms.

Morrison, G. R., Ross, S. M., Kemp, J. E., \&, Kalman, H. (2010).Designing effective instruction: Applications of instructional design $\left(6^{\text {th }}\right.$ Ed.), New York, NY: Wiley.

National Center for Education Statistics. (2000). Teacher use of computers and the Internet in public schools .Washington, D. C.: US Department of Education.

National Research Council (1996). National Science Education Standards. Washington, DC: The National Academies Press. https://doi.org/10.17226/4962.

Roblyer, M. D., \& Jack, E. (2000).Integrating Educational Technology into Teaching. ( $\left.2^{\text {nd }} E d.\right)$. Merrill, an imprint of Prentice Hall. 
International Journal of Innovation in Teaching and Learning (IJITL)

Volume IV- Issue II (December, 2018)

Wallace, R. M. (2011). Using the Internet to Improve Student Learning and Achievement (Unpublished Master's Thesis). Northern Michigan University, USA. 